\title{
Tipificación de un sistema integral de lechería familiar en Zacatecas, México
}

\section{Typification of integrated family dairy systems in Zacatecas, Mexico}

\author{
Ricardo A. Sánchez Gutiérreza, Jorge A. Zegbe Domíngueza, \\ Héctor Gutiérrez Bañuelosb
}

\begin{abstract}
RESUMEN
El objetivo fue determinar las características sociales, económicas, agrícolas y pecuarias de las unidades de producción (UP) en Monte Escobedo, Zacatecas. Se aplicaron 73 encuestas a productores de mayo a julio del 2011. El cuestionario se dividió en dimensiones sociales, económicas, agrícolas, de alimentación y reproducción, de manejo y sanidad, y suelo. El desarrollo de la metodología consistió en ponderación de variables por cada dimensión, análisis de componentes principales y una matriz de posicionamiento. Los tres primeros componentes principales explicaron el $72 \%$ de la variación total. El $82 \%$ de los responsables de las UP son del sexo masculino, ambos sexos saben leer y escribir, los ingresos provienen de la producción agrícola y pecuaria, generalmente por la venta de grano de maíz, becerro en pie, leche fresca y el queso tipo añejo. El primer grupo se caracterizó por alta producción de leche, $78 \mathrm{~L}$ por día, y cuentan con maquinaria de alto nivel tecnológico. El segundo grupo con producciones de $74 \mathrm{~L}$ por día, sin embargo no cuentan con maquinaria agrícola propia. El tercero tiene producciones de leche de 38 L por día, su maquinaria es propia, sin embargo realizan prácticas convencionales. El cuarto grupo se caracteriza por realizar prácticas convencionales, pero el $\mathbf{1 0 0} \%$ de los productores dan valor agregado a la leche, al producir queso añejo. La tipificación de los productores mostró que los sistemas de producción son extensivos y su tendencia es hacia la especialización, debido al potencial que tienen con la elaboración de queso añejo.
\end{abstract}

PALABRAS CLAVE: Sistema tradicional, Ganadería, Agricultura, Queso añejo.

\begin{abstract}
The aim was to determine the social, economic, agricultural and livestock characteristics of the production units (PU) in Monte Escobedo, Zacatecas. Seventy three (73) surveys were applied to producers from May to July, 2011. Questionnaire were divided into social, economic, agriculture, feeding and reproduction, management and health, and soil area. Methodology development involved, weighting variables for each dimension, principal component analysis and positioning matrix. The first three principal components explained $73 \%$ of total variation. Eighty two (82) percent of people in charge of PU are male, both sex are literate, income come from crop and livestock production, usually from corn grain, calf, fresh milk, and aged type cheese. The first group was characterized by high milk production, 78 L per day, and have high-tech equipment. Second group with productions of $74 \mathrm{~L}$ per day; however they do not have their own farm machinery. Third group had milk productions of $38 \mathrm{~L}$ per day, their machinery is proper, however perform conventional practices. The fourth group is characterized by performing conventional practices, but $100 \%$ of the producers give added value to milk, producing aged cheese. Producers' characterization showed that production systems are extensive and its tendency is towards specialization to process aged cheese.
\end{abstract}

KEY WORDS: Traditional systems, Livestock, Agriculture, Aged cheese.

La diversificación de un sistema de producción genera una fuente importante de alimento e
Diversification of a production system generates

a significant source of feed and income for

Recibido el 16 de julio de 2014. Aceptado el 1 de septiembre de 2014.

a Campo Experimental Zacatecas. INIFAP. Km. 24.5 Carretera Zacatecas-Fresnillo, 98500 Calera de V.R. Zacatecas, México. sanchez.ricardo@inifap.gob.mx Correspondencia al primer autor.

b Facultad de Medicina Veterinaria, Universidad Autónoma de Zacatecas. México. 
ingresos económicos para el sostén y desarrollo de las mismas unidades. En México, la producción de leche se lleva a cabo en diversas condiciones agroecológicas, socioeconómicas y tecnológicas; es decir, diferentes sistemas de producción. El sistema especializado en zonas áridas, el doble propósito en la zona tropical y el familiar que se ubica en las zonas templadas $(1,2)$. Este último sistema se caracteriza en que la fuente de mano de obra, el manejo y cuidado de la unidad de producción, provienen de la propia familia, pero cuando se requiere de tareas más específicas como la cosecha y conservación de forraje, contratan personal de la región $(3,4)$. En el estado de Zacatecas la producción se localiza en la región semiárida-templada y se caracteriza por ser un sistema de lechería familiar(5). Este sistema contribuye a la producción nacional de leche con el $1.5 \%$ y cuenta con un inventario aparente de 83,585 cabezas de ganado(6). Dentro de los ejes socioeconómicos pecuarios del Estado, se considera como la segunda cadena en importancia; no obstante, su debilidad es la reducida sustentabilidad(7).

En Monte Escobedo, Zacatecas, se ha identificado un sistema de producción que se considera integral, debido a las vías de desarrollo que han mostrado ante los retos de la globalización y migración. Desde los años 70s se han implementado estrategias que se enfocan en el rediseño del sistema de producción convencional; esto les ha llevado a manejar de manera eficiente tanto sus recursos naturales como la producción de leche, becerro y queso tipo añejo. Este último producto ha sido de gran importancia en las dos últimas décadas, en términos de ventas e ingresos constantes en mercados regionales, entre 15 y $30 \%$, e internacionales, como Estados Unidos de Norteamérica, cuya demanda es mayor al $70 \%$ como resultado de un nicho de mercado nostálgico demandado por los connacionales que viven del otro lado de la frontera norte de México(8). Estos productores han mejorado las prácticas de manejo de los hatos para continuar viviendo de sus actividades. Sin embargo, hasta ahora, no se cuenta con información sobre la system support and development. Milk production in Mexico occurs under diverse agroecological, socio-economic and technological conditions within different production systems. Three of the principal systems used in the country are the specialized system used in arid zones, the double-purpose system used in tropical zones, and the family systems used in temperate zones $(1,2)$. The third is characterized by its use from family members as the primary labor force, and production unit handling and care practices. Workers are hired only for specific tasks such as forage harvest and storage $(3,4)$. Milk production in the state of Zacatecas, Mexico, is largely located in its semiarid-temperate zone and mostly involves family dairy systems(5). This region accounts for $1.5 \%$ of national milk production from an apparent inventory of 83,585 head of cattle(6). Economically, dairy farms constitute the State's second most important livestock production sector, although it is compromised by low sustainability(7).

In Monte Escobedo, Zacatecas, dairy producers have developed a production system that can be considered integrated based on its successful growth despite the challenges of globalization and migration. Beginning in the 1970s, they implemented strategies aimed at redesigning the conventional production system. This has allowed them to make better use of their natural resources, and increase the efficiency of milk, calf and aged cheese production. Cheese production has become increasingly important for these systems over the last $20 \mathrm{yr}$, with 15 to $30 \%$ increases in national sales and income. Growth in international cheese sales has jumped by $70 \%$ due to demand generated by Mexican immigrants in the United States(8). Among other strategies, these producers have improved herd management practices to allow them to continue earning a living from their production units. Although these systems have proved successful, no data is available on their current situation and the distinguishing characteristics of their production units (PU). As a result, it is difficult to identify their strengths and weaknesses, to detect any threats to their continued growth 
situación actual y características de las unidades de producción (UP). Esto ha hecho difícil identificar sus fortalezas y debilidades para proponer alternativas de mejora. Por lo tanto, la tipificación de las UP podría detectar fortalezas, debilidades y amenazas de los sistemas agropecuarios existentes $(9,10)$.

El objetivo fue determinar las características sociales, económicas, agrícolas y pecuarias de las UP en Monte Escobedo, Zacatecas, así como proponer estrategias que ayuden a mejorar al desarrollo. Los resultados de este trabajo ayudarán a la toma de decisiones de los productores o gobierno del Estado, en la planeación del desarrollo de los sistemas de doble propósito de esta región.

Se caracterizó un sistema de producción de doble propósito de Monte Escobedo, mediante el levantamiento de encuestas a productores de la región en 2011. El área de estudio se localizó al suroeste del Estado, cuyo clima es semiárido templado con altitudes que varían de 1,500 a 2,500 msnm. La temperatura media anual, mínima y máxima es $18{ }^{\circ} \mathrm{C}, 12$ ㅇ C y $24 \stackrel{\circ}{ } \mathrm{C}$, respectivamente. La precipitación media anual varía de 700 a $800 \mathrm{~mm}$, cuya ocurrencia es mayor en los meses de junio a octubre(11). Las principales actividades que se practican son la pecuaria con 93,438 ha (58 \%), la forestal con 57,996 ha (36 \%) y la agrícola con 10,212 ha $(6 \%)$.

Para calcular el tamaño de la muestra se utilizó la lista de socios activos de la unión ganadera local y se seleccionó al azar un $10 \%$ de los productores. La colección de datos se hizo con la aplicación de 73 encuestas a productores en sus propias explotaciones de mayo a julio del 2011. La entrevista incluyó un cuestionario con 55 preguntas, de ellas 49 fueron cerradas y el resto abiertas. El cuestionario se dividió en dimensiones sociales (9), económicas (5), agrícolas (14), de alimentación y reproducción (11), de manejo y sanidad (12) y suelo (4).

El desarrollo de la metodología para tipificar a los productores consistió en tres pasos: and to propose alternative strategies for their improvement $(9,10)$.

The present study objective was to describe the social, economic, agricultural and livestock traits of family dairy PU in Monte Escobedo, Zacatecas, and propose strategies for their improved management. The results will aid regional producers and the state government in decision-making as they develop dual-purpose systems in this region.

Producer interviews were conducted in Monte Escobedo in 2011 to characterize its dualpurpose production systems. The study area is located in southwest Zacatecas, in an area of semiarid-temperate climate between 1,500 and $2,500 \mathrm{~m}$ asl. Average annual mean temperature is $18{ }^{\circ} \mathrm{C}$, minimum temperature is $12{ }^{\circ} \mathrm{C}$, and maximum temperature is $24{ }^{\circ} \mathrm{C}$. Mean annual rainfall is 700 to $800 \mathrm{~mm}$, most of which occurs between June and October(11). The main productive activities in the state (by hectares and percentages) are livestock $(93,438 \mathrm{ha}$; $58 \%)$; forestry $(57,996 ; 36 \%)$ and agriculture $(10,212 ; 6 \%)$.

Sample size was calculated using an active members list from the local farms union from which $10 \%$ of producers were chosen at random. Data collection was done by surveying 73 producers on their ranches between May and July 2011. Each interview included a questionnaire with 55 items: 49 closed and 6 open. The items were divided into six dimensions: social (9 questions); economic (5); agricultural (14); feeding and reproduction (11); management and hygiene (12); and soils (4).

The surveyed producers were typified using three data analysis steps: weighting of variables for each dimension; principal components analysis; and matrix plotting.

First, each producer's selection criteria (i.e. variables) were quantitatively weighted, and each added according to its dimension. The social dimension included nine variables: age; sex; education level; literacy; years of experience 
ponderación de variables por cada dimensión, análisis de componentes principales y matriz de posicionamiento.

En el primer paso se ponderaron cuantitativamente los criterios de selección (variables) de cada productor, y a su vez, se sumaron cada una de ellas de acuerdo a su dimensión. La dimensión social consideró: edad, sexo, escolaridad, alfabetismo, años en la ganadería, principal actividad, asistencia técnica, dependencia de mano de obra y número de familiares que dependen de la UP. La dimensión económica contempló: apoyos de gobierno, producción de leche total y vaca/día, venta de leche o de algún producto con valor agregado. La actividad agrícola incluyó: tamaño de la superficie, número de superficie utilizada para pastoreo y agricultura, áreas de temporal y riego, especies forrajeras que siembran y las características de la semilla, tipos de maquinaria (animal o mecánica), adquisición de maquinaria, características de la sembradora, fertilizantes utilizados (orgánicos e inorgánicos) y la forma de conservación de forraje. La dimensión de alimentación y reproducción se determinó con la etapa fisiológica o época que suplementa o complementa a los animales, cantidad de concentrado y forraje que ofrece, raza del ganado, programa de mejoramiento genético que realiza, método por el que se cubren las vacas y diagnóstico de gestación que realiza. En la dimensión de manejo y sanidad se utilizó: método por el que se identifica al ganado, tipo de registro que lleva a cabo, número de ordeñas al día y tipo de conservación de la leche, cantidad de veces que detecta mastitis, aplicación de vacunas y desparasitación al año. Finalmente, la dimensión suelo estuvo constituida por: la cantidad de veces que se realiza análisis de suelo, profundidad de suelo en áreas agrícolas, problemas frecuentes y prácticas que realizan para la conservación.

Con la ponderación de cada dimensión, se realizó el análisis de la información con la técnica multivariada por componentes principales (ACP) incluyendo todas las dimensiones; lo anterior in ranching; main activity; technical assistance; dependence on labor; and number of family members dependent on the PU. The economic dimension included five variables: government subsidies; total milk production; daily milk production $(\mathrm{L} / \mathrm{cow} / \mathrm{d})$; sales of milk and of any value-added products. Fourteen variables were included in the agricultural activity dimension: surface area; percentage area used for grazing; percentage used for agriculture; areas depending on rainfall; those depending on irrigation; forage species sowing; forage seed characteristics; machinery types (animal or mechanical); machinery acquisition; sower characteristics; fertilizers used (organic and inorganic); and forage storage technique. Feeding and reproduction were covered by the variables physiological age or season at which animals are supplemented or complemented; amount of concentrate and forage offered; cattle breed; genetic improvement program; breeding method; and pregnancy diagnosis method. Management and hygiene encompassed seven variables: cattle identification method; type of registration; milkings per day; milk preservation method; number of mastitis tests; number of vaccinations per year; and number of dewormings per year. The soil dimension included four variables: number of soil analyses; soil depth in agricultural areas; frequent problems; and soil conservation practices.

Second, as each dimension was weighted, a multivariate principal components analysis (PCA) was run including all dimensions. This helped to reduce variability to a minimum number of new dimensions, that is, the principal components $(P C)(12,13)$.

Third, the data were standardized in a normal distribution and a matrix generated in which all the producers were plotted based on the PC. The matrix represents an interaction between the axes, forming four quadrants into which each producer was plotted $(7,14)$. The first quadrant contained producers with a high level of technology use; the second contained those with high production and a moderate technology 
sirvió para reducir la variabilidad total a un número mínimo de nuevas dimensiones denominadas componentes principales (CP) $(12,13)$.

En el tercer y último paso, mediante una estandarización de los datos en una distribución normal, se elaboró una matriz de posicionamiento de todos los productores en base a los componentes principales. Dicha matriz se representa con una interacción entre los ejes de una gráfica, donde hay cuatro cuadrantes que indican el posicionamiento de cada productor $(7,14)$. En el primer cuadrante se ubican productores con alto nivel de tecnológico, en el segundo con alta producción y medio nivel tecnológico, el tercero con baja producción y el cuarto con alto nivel de valor agregado. La caracterización y recomendaciones para cada cuadrante se describieron por separado.

Los resultados mostraron que el $82 \%$ de los responsables de las UP son del sexo masculino y saben leer y escribir. Los ingresos provienen de la producción agrícola y pecuaria, generalmente por la venta de grano de maíz, becerro en pie, leche fresca y el queso tipo añejo; estos dos últimos también son para autoconsumo. El 70 al $80 \%$ de la superficie es para pastoreo y el resto se dedica a la actividad agrícola, fundamentalmente para la siembra de maíz (Zea maiz) como forraje y avena (Avena sativa). El $90 \%$ de los productores dependen totalmente de la estación lluviosa. Las fuentes de fertilizantes que se aplican son de origen inorgánico y orgánico; de este último, se usa el estiércol que se genera en las propias instalaciones. Se realiza análisis de suelo; sin embargo, la dosis de fertilización no se ajusta a los requerimientos de los cultivos, y por otro lado el $100 \%$ de las áreas tienen problemas de baja fertilidad y $\mathrm{pH}$.

En la estructura del hato vacuno, la raza que predomina es la Criolla, ya que ha sido seleccionada por su rusticidad y adaptabilidad al ambiente. Las fuentes de alimentación del ganado provienen del pastizal, de los cultivos use level; the third contained those with low production; and the fourth those with high added value. Characterization and recommendations for each quadrant are described separately.

Survey results indicated that $82 \%$ of the PU managers were men who know how to read and write. Income came from agricultural and livestock production, mostly sale of corn, live calves, fresh milk and aged cheese. Both milk and cheese production were also used for household subsistence. From 70 to $80 \%$ of PU area was used for grazing and the remainder for production of forage, primarily corn (Zea mays) and oats (Avena sativa). Most (90\%) of the producers depended completely on rainfall. Fertilizers used for agriculture were both inorganic and organic (i.e. manure generated within the PU). The producers did do soil analyses, but fertilization was not adjusted to crop needs, which is why all the agricultural areas had low fertility and pH problems.

Criollo was the predominant breed used by the producers since it has been selected for its robustness and environmental adaptability. Cattle were fed on pastures, crops and commercial concentrate. Reproduction was by natural mount and no pregnancy diagnosis was done. Records were only kept of deworming frequency. Milking was done once daily and no technology was used for milk preservation.

The three principal components explained $72 \%$ of total variation. The first principal component was dominated by most of the dimensions, save the social dimension, which dominated the second component. This was corroborated by the correlation between the first two PC and the original variables (Table 1 ).

Based on the first two PC, the producers were classified into four groups (Figure 1). Groups 1 and 2 had similar characteristics, although Group 1 stood out for having the highest level of specialization, seed type used, use of a seed sower, mechanical milking, and greater experience due to age. The first two groups 
Cuadro 1. Componentes principales (PC) y su contribución a la explicación de la variación total para los factores sociales, económicos, agrícolas y pecuarios

Table 1. Principal components (PC) and their contribution to explaining total variation for social, economic, agricultural and livestock dimensions

\begin{tabular}{lcccccr}
\hline Dimension & PC1 & $r$ & PC2 & $r$ & PC3 & $r$ \\
\hline Social & 0.090 & 0.138 & 0.909 & 0.929 & 0.243 & 0.237 \\
Economic & 0.429 & 0.658 & -0.017 & -0.018 & -0.423 & -0.413 \\
Agricultural & 0.547 & 0.838 & 0.088 & 0.09 & 0.144 & 0.141 \\
F and R & 0.433 & 0.663 & -0.093 & -0.095 & 0.535 & 0.523 \\
M and H & 0.366 & 0.561 & 0.189 & 0.193 & -0.645 & -0.631 \\
Soils & 0.434 & 0.665 & -0.349 & -0.357 & 0.197 & 0.193 \\
Root vector & 2.35 & & 1.04 & & 0.96 & \\
Variation explained, \% & 39.2 & & 17.4 & & 15.9 & \\
\hline
\end{tabular}

$\mathrm{r}=$ Association between original variables and first three principal components.

$\mathrm{F}$ and $\mathrm{R}=\mathrm{Feed}$ and reproduction; $\mathrm{M}$ and $\mathrm{H}=$ Management and hygiene.

y del concentrado que comercializan empresas.

El método de reproducción es la monta natural y no realiza el diagnóstico de gestación. Los únicos datos que se registran son para el control del desparasitante. El ordeño se realiza una vez al día y no cuentan con alguna tecnología para conservar la leche.

Con base en el análisis, los tres primeros componentes principales (CP) explicaron el $72 \%$ de la variación total. El primer CP estuvo dominado por la mayoría de los factores, excepto por el factor social, el cual dominó el segundo componente. Lo anterior se corroboró con la correlación entre los dos CP y las variables originales (Cuadro 1).

De acuerdo con los dos primeros componentes principales, los productores se clasificaron en cuatro grupos (Figura 1).

Las características del grupo uno y dos fueron similares; sin embargo el grupo uno sobresalió con más alto nivel de especialización, por su semilla, sembradora y máquina de ordeño; también el grupo uno es el que tiene mayor experiencia debido a su edad. Los dos primeros grupos hicieron la diferencia con los restantes en tamaño de superficie, producción de leche differed from the others in terms of area, milk production and number of cows milked. Groups 3 and 4 differed in machinery acquisition, government subsidies, and corn seed used (Group 4 used F2) (Table 2).

For Group 1, strategy improvements should focus on implementing a feed program that meets basic maintenance and production needs

Figura 1. Localización espacial de los productores de acuerdo a los dos componentes principales.

Figure 1. Producer location based on first two principal components

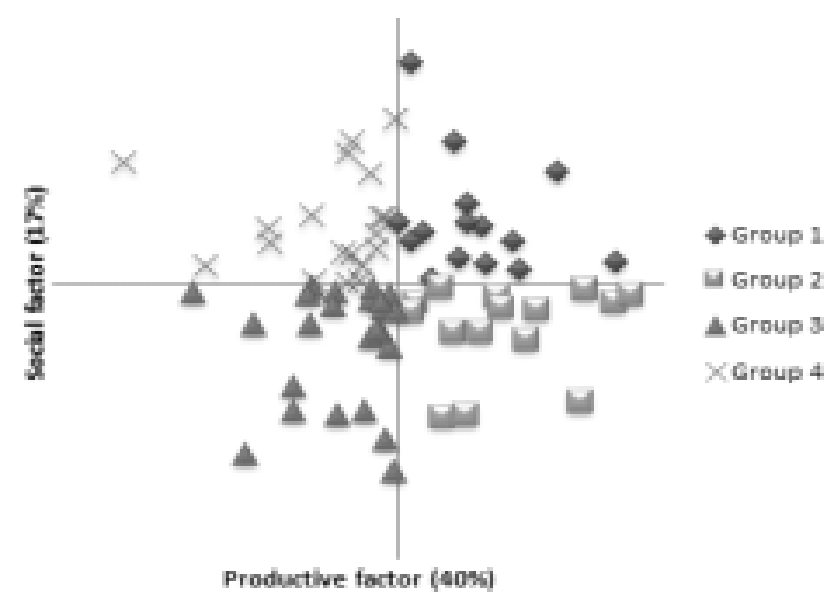


y número de vacas que ordeñan. Las observaciones entre el grupo tres y cuatro fueron la adquisición de maquinaria, apoyos de gobierno y el tipo de semilla que utilizan para la siembra de maíz, ya que el grupo cuatro utiliza F2 (Cuadro 2).

Las estrategias para el primer grupo deberían dirigirse a implementar un programa de alimentación para satisfacer las necesidades básicas de mantenimiento y producción de acuerdo a la época del año(15). Capacitar al personal con buenas prácticas de higiene en los procesos de pre-ordeño, ordeño y postordeño(16) y en la interpretación de los análisis de suelo para suministrar los nutrientes necesarios para los cultivos(17). Fomentar el uso de leguminosas forrajeras que tengan potencial en la región.

En el Grupo 2 es necesaria la adquisición de maquinaria agrícola, organizar asociaciones o according to season(15). Personnel need to be trained in proper hygiene practices during the pre-milking, milking and post-milking processes(16), and interpreting soil analyses to administer the nutrients needed by the forage crops(17). Use of forage legumes appropriate for the region would clearly benefit these PU.

Group 2 would gain from a number of measures. The primary ones are acquiring agricultural machinery, organizing associations or cooperatives for producing aged cheese, and training in forage storage, particularly ensiling of corn. They could also profit from an improvement program for criollo corn varieties, or from research using improved seed recommended for this region. Finally, they need further training in hygiene practices and deworming.

Those Group 3 producers that received government subsidies should to use them to

Cuadro 2. Características sociales, agrícolas y pecuarias de las unidades de producción en Monte Escobedo, Zacatecas Table 2. Social, agricultural and livestock characteristics of production units in Monte Escobedo, Zacatecas

\begin{tabular}{lcccc}
\hline Variable & Group 1 & Group 2 & Group 3 & Group 4 \\
\hline Representation by group, \% & 20.5 & 20.5 & 33.0 & 26.0 \\
Age, yr & 60 & 44 & 40 & 58 \\
Production area, ha & $20-90$ & $20-90$ & $<20$ & $<20$ \\
Milk production, L/d & 78 & 74 & 38 & 35 \\
Cows in milking & 14 & 13 & 7 & 8 \\
Added value of product & 80 & 54 & 80 & 100 \\
Machinery acquisition & Owned & Rented & Owned and rented & Rented \\
Forage (corn) preservation & Silage & Silage-hay & Hay & Hay \\
Sire breed & Swiss & Charolaise & Crosses and & Crosses and \\
& & & Criollo & Criollo \\
Deworming / year & 2 & 2 & 1 & 1 \\
Mastitis detection and control / yr & 1 & 0 & 0 & 0 \\
Government subsidies & 70 & 60 & 41 & 60 \\
Forage seed type (corn-oats) & Hybrid- certified & Criolla-certified & Criolla-certified & F2-uncertified \\
Forage administered, kg/cow & 8 & 10 & 8 & 5 \\
Concentrate administered, kg/cow & 3 & 4 & 2 & 2 \\
Milking type & Mechanical & Manual & Manual & Manual \\
Corn sower type & Precision & Precision & Mechanical & Mechanical \\
\hline
\end{tabular}


cooperativas para transformar la leche a queso añejo. Capacitarse en la conservación de forrajes, especialmente el ensilado de maíz. Llevar a cabo un programa para la producción de semilla de los mejores materiales criollos de maíz o iniciar trabajos de investigación con semilla mejorada recomendada para esa región. Realizar prácticas de higiene y desparasitación, como la recomendación para el Grupo 1.

Las recomendaciones para el Grupo 3 son: participar en apoyos de gobierno, y los productores que sí los tienen, dirigirlos a la modernización de la maquinaria, sobre todo en ensiladoras y sembradoras de precisión. Seleccionar razas de sementales Suizo, como lo hacen el Grupo 1 y 2. Implementar un programa de alimentación que cubra los requerimientos de los animales en producción. Implementar estrategias de obtención de semilla de maíz como el Grupo 2. Debido a la pequeña superficie que tienen en la UP es necesario adecuar la carga animal al pastizal y llevar a cabo prácticas de conservación de suelo en las áreas tanto de pastizal como agrícolas. Realizar las recomendaciones de higiene y desparasitación.

Para el Grupo 4 es necesario mejorar la producción y tecnificación, deberán dirigirse hacia los procesos de forrajes: uso de semilla con calidad, en maíz la recomendación es la misma que el Grupo 2 y en avena usar semilla certificada o ajustar la densidad de siembra por medio del porcentaje de semilla pura viable. Adquirir sembradoras de precisión y ensiladora para conservar el forraje de maíz. I mplementar programas de alimentación(15). Al igual que el Grupo 3, se deben de realizar prácticas para la conservación de los recursos naturales y seguir las recomendaciones para higiene y desparasitación. En lo que respecta a los dos grupos anteriores, es importante hacer un análisis del canal de comercialización del queso, para tratar de evitar intermediarios y venderlo directo al consumidor.

La producción de leche promedio de estas explotaciones es de $5.4 \mathrm{~L} / \mathrm{vaca} /$ día, inferior a modernize their machinery, especially silage choppers and precision sowers, while those who do not receive them should sign up. Selecting Swiss bulls, as occurred in groups 1 and 2, would improve their herds. They also need to implement a feeding program that meets the needs of producing animals, and strategies for improving corn seed (as in Group 2). The small surface area of these PU requires that they adjust pasture stocking rate, and carry out soil conservation practices in pastures and agricultural areas. The same hygiene and deworming recommendations made for groups 1 and 2 also apply to Group 3.

In Group 4, improvements are needed in production and use of technology. Forage cultivation also requires attention through use of quality seed, following the recommendations for Group 2 for corn, using certified oat seed or adjusting sowing density based on percentage of viable pure seed. Precision sowers are needed as are silage choppers to preserve corn forage. Feed programs would also benefit this group(15). As with Group 3, natural resource conservation measures are needed, and the overall hygiene and deworming recommendations need to be followed.

A marketing analysis would help producers in groups 2 and 3 avoid middlemen, sell their cheeses directly to consumers, and increase income.

Average milk production on these farms was $5.4 \mathrm{~L} /$ cow $/ \mathrm{d}$, noticeably lower than the $15 \mathrm{~L} /$ cow/d reported in Los Altos de Jalisco(18), and the $11.6 \mathrm{~L}$ reported in Michoacán(19). However, this production level is similar to the $6 \mathrm{~L}$ reported for Aculco, State of Mexico(20), and the $7.3 \mathrm{~L}$ reported in Tlaxcala(21). In these two regions, milk production also involves cheese manufacture, which accounts for significant income. In systems like these, where daily milk production is low, supplying fresh milk to collection centers increases the risk of lowering income due to price penalties when milk quality regulations change. Therefore, adding value to 
los producidos en otros sistemas de lechería familiar, donde Arias et a/(18) indican $15 \mathrm{~L} / \mathrm{vaca} /$ día para los Altos de Jalisco, y Sánchez et a/(19) 11.6 L/vaca/día en Michoacán. Sin embargo, son similares a los del municipio de Aculco, Estado de México con 6 L/vaca/día(20) y Tlaxcala con $7.3 \mathrm{~L} / \mathrm{vaca} / \mathrm{dí}$ (21). En ambos lugares la producción de leche está vinculada con la elaboración de quesos y representa un ingreso significativo. En estos tipos de sistemas donde la producción diaria es poca, ser proveedor de leche fresca a centros de acopio aumenta la amenaza de percibir menos ingresos, debido al castigo de precio cuando aplican los cambios a los esquemas de normas de la calidad de leche. Por lo tanto, la técnica de dar valor a la producción es una buena alternativa para generar el autoempleo familiar y la sobrevivencia del propio sistema.

Respecto a la tipificación de los grupos, Espinosa et a/(22) mencionan que los aspectos de tecnificación normalmente son los que hacen la diferencia entre estos, y aquéllos con más alto nivel son los que reciben mayores ingresos. En el presente estudio se observó que los productores con mayor factor productivo (Grupos 1 y 2) tienen un nivel más alto de especialización, mayor superficie y número de vacas. Estos resultados concuerdan con Cesín et al(21), ya que mencionan que ganaderos con mayor número de animales tienden a especializarse en la producción, y en aquellos pequeños, la tendencia a la elaboración de derivados lácteos es alta.

Con la finalidad de que estos sistemas continúen existiendo y generando autoempleos, los objetivos deben enfocarse a incrementar la productividad, siempre y cuando se cuente con un manejo adecuado de los recursos naturales. Para llegar a ello, es necesario implementar el manejo de las tecnologías recomendadas por cada grupo, y promover la adopción de dichas técnicas entre productores donde todavía se practica la agricultura tradicional. Otra acción importante es acceder a los apoyos de gobierno, que han sido creados ex profeso para aquellos their production through cheese making is a promising alternative for generating income and ensuring the survival of their production system.

When typifying dairy production groups, they can be differentiated by their use of technology: the higher the level of technology use the higher the income ${ }^{(22)}$. In the present study, producers with a higher productive factor (i.e. Groups 1 and 2) had a higher level of specialization, greater surface area in use and larger herds. This agrees with Cesín et a/(21), who state that ranchers with large herds tend to specialize their production, while smaller ranchers often produce dairy derivatives.

If these production systems are to continue existing and generating self-employment, producers need to focus on increasing their productivity, as long as they properly manage natural resources. Practical measures toward this end include taking advantage of government subsidies and researching optimum natural resources. Government subsidies are an important source of aid, and are created expressly for producers who have not yet received them. In the present case, research is needed into the forage species to identify those best adapted to the region and production system.

In addition, the technological recommendations described for each group need to be implemented, and these techniques promoted among traditional producers. Promoting new production technologies can benefit from in situ demonstration to accelerate transference of new techniques. In a study of bean production, demonstration parcels were found to be the most efficient means of showcasing new techniques, as long as an adequate producer-demonstrator is chosen(23). Rogers(24) observes that in every social system there are individuals known by their contemporaries to be innovators. These individuals are more integrated into the production system and anticipate new technologies. Their contemporaries then consult with the innovators about these technologies. 
productores que no cuentan con ellos. Acosta et a/(23) mencionan que para difundir las tecnologías de producción en el cultivo de frijol, las parcelas demostrativas in situ son el canal más eficiente, siempre y cuando se seleccione un productor-demostrador adecuado, con la intención que éste acelere el proceso de transferencia, lo cual ha sido consignado por Rogers(24). Este autor señala que en un sistema social existen individuos que son reconocidos como innovadores por sus compañeros. Estos están más integrados al sistema de producción y expectantes de nuevas tecnologías. A ellos recurren compañeros productores a pedir información o consejos sobre alguna nueva tecnología. Para poder realizar las recomendaciones de los grupos, será necesario identificar aquellos productores líderes e implementar tecnologías exitosas disponibles. Con respecto a la investigación, se deben llevar a cabo evaluaciones de variedades de especies forrajeras, para identificar cuál de ellas se adapta a esa región.

Se concluye que la tipificación de los productores de Monte Escobedo mostró que los sistemas de producción son extensivos y su tendencia es hacia la especialización debido al potencial que tienen con la elaboración de queso añejo. En todos los sistemas existe un gran vínculo entre la ganadería y la agricultura, el cual provee alimento y recursos económicos a las unidades de producción. Basado en el posicionamiento de los productores, la tipología de los grupos se caracterizó por: El grupo 1 tiene a los productores con más experiencia, cuentan con grandes superficies, la producción y el nivel de especialización es alto. Es conveniente capacitaciones con objetivo de reducir costos y mejorar la higiene, en alguno de ellos se podrán establecer parcelar demostrativas o evaluación de materiales forrajeros. Aunque el Grupo 2 tiene grandes superficies y alta producción, su nivel de especialización es medio debido a que todavía realizan prácticas convencionales. Es necesaria la adquisición de maquinaria y que asistan a las capacitaciones, ya que son jóvenes y es probable que la adopción de tecnologías
To implement the recommendations made here, leading producers would need to be identified to aid in promoting successful technologies.

At the time of the survey, the production systems in Monte Escobedo were extensive and tended towards specialization to take advantage of aged cheese production. Agriculture and ranching were closely linked in all the production systems since growing feed crops provides inputs for cattle, as well as additional income. Group 1 encompassed the most experienced producers with the largest areas and the most specialized production. Producers in this group could benefit from training to reduce costs and improve hygiene practices, but could also be recruited to plant demonstration parcels and research forage materials. Group 2 producers also have large areas and high production, but their level of specialization is moderate since they continue using conventional techniques. They are younger than Group 1 producers, could benefit from training and acquiring machinery, but are likely to quickly adopt new technologies. Group 3 producers are the youngest, have the lowest milk production, smaller areas and still use a conventional system. This group also receives the lowest percentage of government subsidies, and requires better information on how to access this aid. Production area is also small in Group 4, although the average is larger than in Group 3; their experience may have led these producers to have the highest percentage of added value to their milk. However, they need to implement strategies to ensure that their added value arrives directly to consumers.

End of english version

sea rápida. El Grupo 3 tiene la edad más joven, baja producción de leche, cuenta con reducida superficie y el sistema todavía es convencional. Desafortunadamente es el grupo que cuenta con el menor porcentaje de apoyos de gobierno, por lo que es urgente que se informen acerca de ellos. 
En el Grupo 4 la superficie también es reducida, la edad media es mayor que el grupo tres, pudiera ser que la experiencia los ha llevado ser el grupo con el más alto porcentaje de valor agregado a la leche. Para ellos es necesario implementar estrategias para que ese valor agregado llegue directo a los consumidores.

\section{LITERATURA CITADA}

1. Espinosa GJA, Wiggins S, González OAT, Aguilar BO. Sustentabilidad económica a nivel de empresa: aplicación a unidades familiares de producción de leche en México. Tec Pecu Mex 2004;42(1):55-70.

2. García MJ G, Mariscal ADV, Caldera NNA, Ramírez VR, Estrella QH, Núñez DR. Variables relacionadas con la producción de leche de ganado Holstein en agroempresas familiares con diferente nivel tecnológico. Interc 2007;32(12):841-846.

3. Lara CD, Mora FJS, Martínez DMA, García DG, Omaña SJM, Gallegos SJ. Competitividad y ventajas comparativas de los sistemas de producción de leche en el estado de Jalisco, Mexico. Agrociencia 2003(37):85-94.

4. Améndola MRD, Cortez AJ. Sustentabilidad de sistemas lecheros del noroeste de Michoacán. Velasco ZE, et al. editores. Congreso Internacional de Manejo de Pastizales, Tuxtla Gutiérrez, Chiapas. 2010.

5. Roman PH, Núñez HG, Vera AHR. Proyecto nacional de capacitación para la competitividad de la producción de leche de bovino en México. En: Salinas GH, et al. editores. Estrategias de investigación para la innovación tecnológica: principales logros en el Norte-Centro de México. 1 era ed. Coahuila, México. 2010.

6. Servicio de información Agroalimentaria y Pesquera (SIAP). Anuario estadístico de la producción agrícola. 2012.

7. Sánchez TBI, Rumayor RAF. Evaluación del entorno para la innovación tecnológica en Zacatecas: identificación de las cadenas productivas relevantes. Campo Experimental Zacatecas. CIRNOC. INIFAP. 2010. Publicación especial No. 18.

8. Guzmán HE, Manzo RF, Delgado WR, Martínez ST. Estrategias de adecuación del sistema de producción de queso añejo a un escenario de globalización (binomio migración-mercado nostálgico). El caso de la laguna grande, Monte Escobedo, Zacatecas, México. En: Álvarez MA, editor. Agroindustria rural y territorio. Tomo II Nuevas tendencias en el análisis de lechería. 1a ed. Estado de México. 2007.

9. Landis E, Modelling farm diversity. New approaches to typology building in France. Agric Sys 1998;58(4):505-527.

10. Milan MJ, Bartolome J, Quintanilla R, García MD, Espejo M, Herráiz PL, et al. Structural characterization and typology of beef cattle farms of Spanish wooded rangelands (dehesas). Livest Sci 2006(99):197-209.

11. Medina GG, Ruiz CJA. Estadísticas climatológicas básicas del estado de Zacatecas (Período 1961-2003). 1a ed. México: INIFAP; 2004.

12. Wold S, Esbensen K, Geladi P. Principal component analysis. Chem Intell Lab Syst 1987(2):37-52.

13. Lezzoni AF, Pritts MP. Application of principal component analysis to horticulture research. Hort Sci 1991;26(4):334338.

14. Rincón VF, Echavarría ChF, Rumayor RAF, Mena CJ, Bravo LAG, Acosta DE, et al. Cadenas de sistemas agroalimentarios de chile seco, durazno y frijol en el estado de Zacatecas: una aplicación de la metodología ISNAR. Campo Experimental Zacatecas. CIRNOC. INIFAP. 2004. Publicación especial No. 14.

15. Gutiérrez BH, Aguirre CCE, Ibarra FJ M, González CF, Gutiérrez LR, Martínez TG. Alimentación y manejo de bovinos en agostadero durante épocas de sequía. Campo Experimental Zacatecas. CIRNOC. INIFAP. 2012. Folleto técnico No. 45.

16. Montero LM, Tepal CJA, Hernández AL, Ontiveros CML, Blanco OMA. Procesos de ordeño y calidad de la leche. En: Vera $A H R$, et al. editores. Producción de leche de bovino en el sistema familiar. 1era ed. Veracruz, México. 2009.

17. Flores OMA, Palomo RM, Figueroa VU. Producción de forraje con cereales de grano pequeño. Campo Experimental Zacatecas. CIRNOC. INIFAP. 2011. Folleto técnico No. 37.

18. Arias LE, Tovar MA, Núñez G, Bonilla JA, Osuna ES, Estrada E, Villareal JH. Tipología de los sistemas de lechería familiar en los altos de Jalisco México. En: Flores NM, et al. editores. Reunión Internacional Conjunta de Manejo de Pastizales y Producción Animal. Zacatecas, México 2012:16-21.

19. Sánchez GL, Solorio RJ, Santos FJ. Factores limitativos al desarrollo del sistema familiar de producción de leche en Michoacán, México. Cuad Des Rur 2008;5(60):133-146.

20. Castañeda MT, Boucher F, Sánchez VE, Espinoza OA. La concentración de agroindustrias rurales de producción de quesos en el noroeste del Estado de México: un estudio de caracterización. Est Soc 2009;17(34):74-109.

21. Cesín VA, Aliphat FM, Ramírez VB, Herrera HJ, Martínez CD. Ganadería lechera familiar y producción de quesos. Estudio en tres comunidades del municipio de Tetlatlahuac en el estado de Tlaxcala, México. Téc Pecu Méx 2007;45(1):6176.

22. Espinoza OA, Alvarez MA, Del Valle M, Chauvete M. La economía de los sistemas campesinos de producción de leche en el Estado de México. Téc Pecu Méx 2005;43(1):3956.

23. Acosta DE, Galindo GG, Cázares EB, Zandate HR, Pérez TH. Guía para el establecimiento, conducción y evaluación de parcelas demostrativas. Campo Experimental Zacatecas. CIRNOC. INIFAP. 2002. Tema didáctico No. 4.

24. Rogers EM. A prospective and retrospective look at diffusion model. J Hea Comm 2004;9(1):13-19. 